\title{
Kristevan Abjection in Nawal El Saadawi's Woman at Point Zero
}

\section{Omar Mohammed Abdullah}

Faculty of Modern Languages and Communication, Universiti Putra Malaysia; omr_muh1985@yahoo.com

Wan Roselezam Wan Yahya

Faculty of Modern Languages and Communication, Universiti Putra Malaysia; roselezam@gmail.com

Hardev Kaur

Faculty of Modern Languages and Communication, Universiti Putra Malaysia; jshardev@yahoo.com

Manimangai Mani

Faculty of Modern Languages and Communication, Universiti Putra Malaysia; manimanggai@hotmail.com

\section{Doi:10.5901/mjss.2015.v6n6s2p80}

\section{Abstract}

It is evident that the second half of the 20th century witnessed a revolution in women's studies, which cite women as the core subject of their focus, starting from Simone de Beauvoir until the present. Women's identities, sexuality, and self-affirmation have been researched in the modern period's theories and literature. As such, Julia Kristeva's theories extend to include those of identity formation. Kristeva's famous essay Powers of Horror: An Essay on Abjection (POH) (1980) discusses the concept of abjection as a means for defining the self and asserting subjectivity. Abjection is a process of expelling and rejecting what is other, what hurts and disturbs the identity. Thus, abjection is considered as a strategy for identity formation as far as it expels things that obstruct the subject from identifying his/her self and acquiring subjectivity. In Nawal El Saadawi's Woman at Point Zero (WPZ), the heroine suffers from hysterical symptoms which prevent her from developing her identity. This paper will look at abjection and its many forms as bisexuality in the first place; also a reference to prostitution and rejected marriage will be introduced due to its relatedness to abjection in WPZ to indicate the way the hysterical heroine gains her subjectivity through these forms by expelling the things which are considered Other to her.

Keywords: Abjection, El Saadawi, Kristeva, Subjectivity, WPZ

\section{Introduction}

The modern era laid more importance to women and the way they live as suffering subjects because of the over rule of men. The $20^{\text {th }}$ century provided many theories and concepts by males and females preaching and guiding on the development of women and their equality with men. For centuries men are the decision makers who decide on behalf of women, which normally produce an impaired situation. For instance, some of the psychoanalytic judgments by Freud and his contemporaries considered women from a male point of view which consequently lack reason according to many modern female theorists. Thus, women need to defend themselves and voice what has been kept unvoiced for centuries. So, female novelists in the $20^{\text {th }}$ century in particular started to present the shortcomings of life imposed on them and the subsequent suffering. Nawal El Saadawi focuses in her oeuvre on the status of women and the means by which women can develop themselves and become normal subjects. This is highlighted in tandem with modern female theorists. Women theorists' concepts came to do justice to women and help them be normal subjects not followers to men. Julia Kristeva is a one of the prominent figures who presented Abjection as a concept that helps women be normal, which will be employed in this study.

\section{Julia Kristeva and Abjection}

Kristeva's theories in the late $20^{\text {th }}$ century cannot be easily accessed and understood. She is a "prolific, eclectic, rigorous, 
difficult, and occasionally outrageous" (Becker-Leckrone 2005) theorist. Her ideas and perspectives on literary discourses do not reveal "clear models of how another reader might produce a sustained literary criticism in her spirit. Nor do they explicitly indicate whether and why one should." (Becker-Leckrone 2005, original emphasis). Leon S. Roudiez uncovers a reality in his introduction to Kristeva's Revolution in Poetic Language (1984), confirming that "Julia Kristeva is a compelling presence that critics and scholars can ignore only at the risk of intellectual sclerosis" which underscores the difficulty in reading and comprehending Kristeva.

Abjection is "not lack of cleanliness or health" it is "what disturbs identity, system, order, what does not respect borders, positions, rules" (POH 1982). It is also "the place where the meaning collapses" the place where 'I' does not exist and threatens life that is why it should be radically excluded (POH 1982) from the place of the living subject, jettisoned away and deposited on the other side of the imaginary border which splits the self from that which threatens it. Hence, Estelle Barrette concludes that "abjection can be understood as an expulsion or rejection of the mother."

In $\mathrm{POH}$, Kristeva rewrites the ideas of Freud and Lacan and comes with a new definition of her own for the concept of human subject construction. Kristeva makes it necessary for the infant to be separated from his mother in order to realize the borders between 'me' and m/other before finding itself in the Symbolic. Lacan holds that the infant encounters his split from the maternal body in the mirror stage to which Kristeva opposes, justifying that the split, the state of abjection happens before the mirror stage since the child develops boundaries through excreting, spitting out the mother's milk, and rejecting the latter's embrace. It is here the infant lives in a crossroad, when he is puzzled between two needs, it yearns to the maternal body on one hand and on the other hand the infant realizes that it needs to break away from the semiotic chora to become a self.

Freud claims that the infant needs to repress his desire for the mother otherwise it would encounter psychological troubles. In this case Freud's claim is validated as far as all the repressed desires when emerge to the surface will cause neurotic disorders. Kristeva's abject on the reverse, remains with the subject and never completely buried in the unconscious same as Freudian desires. The abject keeps haunting the subject as a threat to the boundaries of the self and continues with him on the "periphery of the consciousness" (McAfee 2004). This paper then will explore abjection with its various forms; bisexuality, rejected marriage, motherhood and prostitution in WPZ in order to indicate the way Firdaus, the heroine, managed to gain her subjectivity and freed herself in spite of her death sentence at the end.

\section{Abjection and Self Actualization in WPZ}

The subject's suffering of hysterical symptoms whether they are biologically related to sexuality according to Freud, or ones related to social, economic, religious or political as Irigaray theorized, can all hurt the subject and bring him to the verge of destruction through driving him to a desperate neurotic state. In the case of Firdaus and based on Freudian ideology, the subject can get the cure and be absolved of hysterical symptoms through some cures of which is the talking cure. We witnessed Firdaus relating her story to the psychiatrist which is considered as a cure as it has been employed by Freud with his patients as Dora and Anna $\mathrm{O}$. The cure then may come through the reproduction of the primal scenes of trauma Firdaus suffers as her circumcision experience. As such, reproducing these scenes can act as a cure and provide the subject with a stable psyche but Firdaus' absolvement has been attained through a different technique, abjection.

Kristeva's technique of abjection is a psychic strategy that the subject (Firdaus) uses to fight the destabilizing impact of the abject to reaffirm her identity. According to Kristeva, the symbolic order requires the child to be separated from the maternal body in order to create the autonomous self. Firdaus goes through many processes of rejection, abjection.

In WPZ, Firdaus is highly aware of the loss she experiences during her clitoridectomy. She not only loses physical sensation, but also a psychic bond with the mother. Firdaus's first emotional bond was with her mother, a relationship symbolized by the mirror-like eyes of her mother that she watched and that watched her (WPZ 1982). Later, the "lamps" of those eyes were extinguished and it was as if the woman were dead inside (WPZ 1982). This lost connection may be symbolic of Firdaus's seeing herself in the mirrors of her mother's pupils, entering the language of the father, thereby cutting the tie with her mother's body, and being differentiated into a separate social being. Another explanation, however, is that in participating in her daughter's genital mutilation, the mother broke the bond with her daughter, and Firdaus no longer saw or experienced her mother in the same way.

Firdaus' body has been abjected early in her childhood through the process of circumcision at the hands of her mother. Any link with her mother has been cut, no other ties can bring them together and this leads Firdaus' life into a different detour in which she starts to depend on herself as a separate being. So, this process of deserting the mother is what Kristeva terms abjection and Firdaus has undergone this process early to have an autonomous body. After this 
separation, Firdaus no longer lives in the semiotic chora where everything is provided as food, water, warmth, security that could be satisfied in a single moment of cry or any sign signaled to the mother. Firdaus has been abjected from this chora into a world where men rule, where there is patriarchy and male dominance, where she can be no more than a slave in spite of her being separated from her mother. However, in this hegemonic society, the male discourse takes the lead and controls everything. After her hazardous life in her father's house with her step mother, her memory is deeply marred and the suffering is instilled in her life.

Firdaus then leaves to her uncle's house who sends her to the secondary school where she encounters Miss lqbal who embodies the image of abjection in her adulthood. Miss Iqbal leads Firdaus in a stream of consciousness moment to travel back when she was still a child in her mother's lap. Firdaus' description of Miss lqbal and associating her with her mother in a likeable manner indicates that she yearns to be in that period.

In fact, the abject keeps haunting and disturbing the subject, even though she manages to abject the mother as it has been portrayed in more than one scene, she keeps yearning to a re-union with the mother, and she misses the mother because she is threatened always in the male dominated society. The males she encounters all looted her subjectivity and did not give her a chance to live as a normal subject, all consider her as an object which should be exploited to the bone. That is why she expresses her strong desire to re-unite with her mother to compensate herself and feel the warmth she used to have before, to feel secure as she was because in the patriarchal society she is a target all the time where men are competing to hurt her. This border between subject and abject has been broken and she showed her fascination to Miss Iqbal who resembles a mother to her. Miss lqbal is her teacher in the boarding school who used to comfort Firdaus when she finds her sitting alone in a dark place in the garden crying about the way she lives missing her family and mother. Miss Iqbal takes the role of the mother and provides Firdaus with the warmth and passion she needs that moment and proves to be as a source of help and compassion. This does not stop at this end, but she took the responsibility of the mother and receives the certificate Firdaus was awarded after graduating from high school. Firdaus's union with Miss lqbal proves her yearning to break the rules and return to the chora in which she finds her needs, in which she is satisfied without even asking for her needs.

\section{Bisexuality and Abjection}

In the feminist fiction, female writers worked hard to initiate a discourse in which women can be independent, in which they can construct their own (Symbolic) space where no male can objectify them. This strategy came to light and underscored in postmodern fiction and developed further in postfeminist era. One of the leading figures in this scope is the black American poet Adrienne Rich, whose poetry is dedicated for women in which they stand in the lead. One of the strategies employed by which the male is eliminated is lesbianism/bisexuality. For instance, Rich's poetry underscores lesbianism heavily but it is not for the sake of sex or desire. But, it is a technique, a weapon in which women 'abject' what hinders and obstructs their subjectivity according to Kristeva, and initiate a new discourse wherein they are subjective. On a similar scale, Nawal El Saadawi, although being a Muslim and living in a pure patriarchal society, triggers the element of bisexuality in her novel which is a sign for females that they can build their world, identity and subjectivity away from males, through abjecting them and thus abject the whole symbolic order that keeps objectifying them since their infancy.

Abjection can be read in a different perspective. Besides its being abjecting the mother to develop identity, it can also be abjecting the symbolic in its racial, sexual, social and cultural terms under which the female is controlled. As far as it is interpreted as abjecting what is 'other' to the subject, what hinders the subject's autonomy, then definitely the symbolic controlled by males hinders women's subjectivity and that is why it needs to be abjected. The lesbian/bisexual subtext is one of the strategies through which females can abject, and then break into the symbolic by transgressing its rules because according to the Symbolic, lesbianism is a breach in its system. As far as women are supposed to fulfill the male desire in terms of patriarchy, they should not turn their desire to each other and eliminate the male.

There is a bisexual subtext latent in El Saadawi's WPZ. Fedwa Multi-Douglas confirms that "even a lesbian subtext" (1995) is inherent as one of the ingredients in WPZ but is more like bisexual than lesbian element in the case of Firdaus. She is proved heterosexual through her marriage to Sheikh Mahmoud and her later intercourses with other males that is why she cannot be judged a lesbian. Her relationships with other females are only bisexual which verifies her resorting to females when the males are only shattering her. At the beginning of the novel the psychiatrist (a woman) interviewing Firdaus is portrayed in a scene which carries sexual overtones that connotes a union between her and Firdaus. This union represents the female desire to return to the mother (partner) after being abjected for the second time (first abjection is by the mother while the second is done by the Symbolic). Although abjection means a separation from the mother, for the male it is possible because he will manage to construct his identity and adapt with the ruling symbolic law. But for the female, abjection in a complete way is almost impossible, because, according to Kristeva, it keeps 
haunting the female subject and residing at the periphery of consciousness to interfere whenever it is possible, as in the case of Firdaus. In her case, Firdaus would think of a (re)union with her mother or a substitute mother, represented by the psychiatrist, Miss Iqbal or Sharifa.

The bisexul is set in unclean, improper and defiling scope with other abject entities in the symbolic order. El Saadawi refers, in WPZ, to some sexual elements aiming at destroying the traditional binary of masculine/feminine and on the bisexual subject who transgresses the sexual boundaries of the patriarchal order. When the normal heterosexual relations form a threat to the female's identity and cause her to be an object otherized by the male, females may resort to each other (bisexuality) and abject the established systems of order in which the males rule. In this sense, the bisexual figure can be considered as a rebel against the confinement of women within the hierarchally constructed sexual politics.

The atmosphere in which Firdaus meets the psychiatrist is portrayed as a cell which has a door, no window, dark, and silent which is connotative of a womb. "The closeness," says Multi-Douglass "the privacy in the womblike atmosphere that is the hallmark of Firdaus's narration, is but an external sign of the intimate relationship established between prostitute and psychiatrist" (1995). The sexual atmosphere apparent in Iqbal-Firdaus relationship is undeniable especially when compared to a later similar scene Firdaus lived with a company employer, Ibrahim, whom she loved passionately. The quite similar description of the two scenes reaffirms the bisexual subtext El Saadawi thrusts in Iqbal's episode. In a quiet dark night, Firdaus did not go to sleep and spent sometime in the garden crying because of her miserable life. When approached by lqbal, the latter addresses her "Firdaus, Firdaus, please do not cry" (WPZ 1982). The description of their encounter is explained by Firdaus saying

I held her [Iqbal's] eyes in mine, took her hand in mine. The feeling of our hand touching was strange, sudden. It was a feeling that made my body tremble with a deep distant pleasure ... my fingers held on to her hand with such violence that no force on earth, no matter how great, could tear it away from me. (WPZ 1982)

In this scene we find Iqbal crying because of Firdaus miserable state and beseeching her to stop crying, the furitive touching of hands, and the soft words echo the sexual undertone. This bisexual element is highly confirmed when Firdaus lives the same situation and use almost the same words in another scene with a male, Ibrahim. Definitely, when it is related to male it means a heterosexual relationship full of love and emotions. Explaining Firdaus-Iqbal and FirdausIbrahim encounters, under similar circumstances and with similar words, the writer aims at showing the analogy and making them identical to trigger the sexual element in Firdaus-Iqbal affair. When Firdaus does not feel her subjectivity, and feel her being exploited in the heterosexual space, she resorts to Miss Iqbal, where we encounter the lesbian references, as source of love and protection, a space where she can find her lost voice.

Firdaus later is encountered by Ibrahim in a dark and silent place crying, he asks her "Firdaus, I beg of you. Don't cry" (WPZ 1982). Same as Iqbal encounter, Firdaus repeats her words but not in a homosexual tone now, as her partner is a male whom she loves emotionally. She narrates;

I held his eyes fast in mine. I reached out and took his hands in mine. The feel of our hands touching was strange, sudden. It made my body tremble with a deep, instant pleasure ... my fingers grasped at his hand with such violence that no force in the world, no matter how great, could take it away from me. (WPZ 1982)

The sexual denotations represented in this scene are obvious. The holding of hands, the strange touching, trembling, pleasure, fingers grasping his hand, all carry sexual overtones obvious in the direct use of some words or hidden as what is buried in the use of fingers and hands which refer to the phallus in deep psychoanalytic terms. This language is normal as far as it is heterosexual but compared to lqbal-Firdaus encounter which is done in similar scale, it is pure sexual scene. As referred above, the bisexual element is only another form of abjection employed by the writer to emphasize the weapon employed by women (abjecting the symbolic) in order to create a new discourse in which they can attain their own subjectivity.

Thus, the abject keeps visiting Firdaus and emanates through the memories she remembers when she is with Miss Iqbal. The sexual tendency lurking in Firdaus-Iqbal relationship constitutes clear evidence to Firdaus' desire to reunite with the mother, or a substitute mother. It surfaces clearly in the conversation of Firdaus and her school mate Wafeya who reproaches Firdaus that she talks much about Miss Iqbal as if she is in love with her. Firdaus answers "but she's a woman. How could I be in love with a woman?" (WPZ 1982), says Malti- Douglas, the rhetorical question answers itself (1995).

Such relation of Miss Iqbal and Firdaus is considered a taboo in their own community, but at the same time it is a reference by El Saadawi to attract women's attention to a forgotten fact that they can depend on themselves and achieve their independence from and ( abjection) of the males. But, because "Abjection is the underside of the symbolic. It is what the symbolic must reject, cover over and contain" (Grosz 1990), that is why Miss Iqbal and Firdaus relation does not stand long. The bisexual visualizes her mother in her partner and it is clear through Firdaus' associating Miss Iqbal's eyes to her mother's. In this respect Janna Rinaldi comments 
She [bisexual] likens the intimacy of her relationship to the egg-like fusion that she experienced in the maternal body with her mother. Yet, what happens is two-fold. The woman may realize that she may never be fused with her female partner as she was with her mother. Second, she becomes equally frustrated when she observes that the fusion of intimacy that she experiences with her partner is a lesser re-creation of her linkage with the maternal body, thereby slowing effacing her own perceived autonomy and otherness, while never delivering on the promise of utter unity with the maternal. (WPZ 1982)

Firdaus then can achieve a union with her partner which is similar to the union she used to have with her mother because the mother- daughter bond is stronger and the abject, as mentioned earlier, keeps haunting the subject and threatening it even at a later stage.

In another instance, Firdaus manages to be united with another woman, Sharifa, a prostitute (her name means noble, hence the irony). After breaking loose from Bayoumi, she is sheltered by Sharifa who provides her with lodging, food, clothes and warmth. Sharifa is a new comfort to Firdaus because they both share common grounds in their suffering as females. The unity between Sharifa and Firdaus reminds the latter of the motherly figure of her mother and Miss Iqbal. Firdaus describes Sharifa's eyes saying "her eyes radiating a strong, green light, the colour of the trees and the sky, and the waters of the Nile" (WPZ 1982). Firdaus then becomes "a young novice" in the hands of Sharifa but soon after Sharifa proves to be similar to males in her exploitation of Firdaus. In her apartment later Firdaus complains "I never used to leave the house. In fact, I never even left the bedroom. Day and night I lay on bed, crucified, and every hour a man would come in" (WPZ 1982).

Firdaus then abjects the motherly figure, Sharifa, who exploits her and made her a sexual object out of whom she earns money. But Firdaus abjects this mother, jettisons her because she is a threat to her autonomy. This imaginary union between Sharifa and Firdaus does not stand long, eventhough Sharifa symbolizes the semiotic chora, who provides her with whatever needs she requires. Because, according to Kristeva, subjectivity requires a break from the mother identification of the ' $\mathrm{l}$ ' in order to develop borders between ' $\mathrm{l}$ ' and (m)Other. Firdus deserts Sharifa's house "as a sign of revolt" (Emenyonu and Eke 2010) and by this revolt she rejects motherhood as it is constructed by patriarchal institution.

\section{Abjection and Society}

In another process of abjection, Firdaus abjects the society that keeps curbing her so she rejects the society as far as abjection means getting rid of what obstructs and harms subjectivity. To gain herself, body, and decision, she needs to realize her split from others in social, cultural and sexual perspectives in order to become an autonomous subject. In this case she is also considered as an abject of the symbolic law. In order to construct herself in isolation from the society, she learns the profession of prostitution and exploits her body to achieve what she needs. Nickie Roberts highlights the significance of prostitutes showing that those individuals, as Firdaus, are the first to abject the world, absolve themselves from society control and own their own bodies. These subjects take new routes as prostitution to challenge the dominant rules of the patriarchal system through their rejection to conform to males' rules. Roberts emphasizes that "the whore is seen as dangerously free. Her financial and sexual autonomy strike at the very root of patriarchy, threatening the interests of male moralists and legislators" (1992). This complies with the situation of Firdaus when she abjects herself from the society which keeps subjugating her and thwarts her desire. Even though Firdaus might be considered a victim or a fallen woman, she finds her self-respect in positioning herself and confirms "a successful prostitute was better than a misled saint" (WPZ 1982).

El Saadawi in presenting Firdaus as a prostitute who owns herself, body and desire, is condemning the patriarchal society which keeps women in a dark corner and brings them to light only to satisfy their desires. F. O. Orabueze thinks that El Saadawi shows that the lowest position of women is prostitution not wifehood. Orabueze confirms that in prostitution "a woman becomes a rolling stone without any anchor. At least a married woman can quit her marriage without the husband molesting her" (Emenyonu and Eke 2010). But, Orabueze misses the point that El Saadawi keeps underscoring prostitution as something better than wifehood and, by this, she is satirizing the social circumstances wives live in such communities. El Saadawi mocks wifehood position and considers it crippling the woman more than prostitution. This comes at the tongue of Firdaus who claims that "Now I realized that the less deluded of all women was the prostitute. That marriage was the system built on the cruelest suffering of women" (WPZ 1982). El Saadawi is not encouraging prostitution but in comparison with marriage life, based on what Firdaus went through, prostitution is more respective to the female. It is not a call to hold prostitution, contrarily; it is a call to pay more attention to women as wives. Firdaus as a prostitute is shown as a rival to the phallocentric system. She is more subjective and owns freedom, food and her body, which she missed in her 'saint' life. 
Firdaus after freeing herself from the clutches of males of her society feels estrangement from everything around her, even the earth, sky and trees. She holds

I was like a woman walking through an enchanted world to which she did not belong. She is free to do what she wants, and free not to do it. She experiences the rare pleasure of having no ties with anyone, of having broken with everything, of having cut all relations with the world around, of being completely independent and living her independence completely, of enjoying freedom from any subjection to a man, to marriage, or to love. (WPZ 1982)

In this regard Diana Royer comments that separation, which I consider abjection, is the only form Firdaus has. All relationships have subjected her to the domination and control of others. She acquires her self-control through detachment, abjecting herself from the world around. She also decides to use men for their money the same way as they used her body for their physical desires (Royer 2000).

The last act of abjection which can be highlighted in Firdaus' revolutionary life is her encounter with Marzouk, the pimp. Firdaus can no more take the life of slavery, where she loses her body and become an object controlled by others, and manages to kill Marzouk in self- defense in one of their encounters. She describes her experience:

I raised the knife and buried it deep in his neck and then thrust it deep into his chest, pulled it out of his chest and plunged it deep into his belly. I stuck the knife into almost every part of his body. I was astonished to find how easily my hand moved as I thrust the knife into his flesh, and pulled it out almost without effort (WPZ 1982).

This phallic knife represents Firdaus' reaction to the exploitation she suffers. Specifically, it resembles a reaction to the many rapes she experienced. She is not satisfied with one stab; otherwise she has to avenge herself upon her father, uncle, husband, Bayoumi, Marzouk. The subject of her revenge is Marzouk's body who represents the dominating male order. So she targets his body to achieve the poetic justice she longed for.

Henceforth, the killing of Marzouk "has a cathartic effect on Firdaus: such violent action was Firdaus' first action as a 'conscious subject' " (Coin 2006). This act of murder represents the emancipation of Firdaus which allows her to construct her subjectivity. She encountered the problem of self-definition and was an object most of her life. Thus, her destruction of Marzouk and the money she earns from the prince she slept with later empowered her to react against the motives of hysteria, exploitation, and suffering and liberated herself though abjection which leads to her actualization. These acts enable her to know the feeling of power and subjectivity. She feels she is "destroying all the men [she] had ever known, one after the other in a row" referring to her uncle, father, husband, Bayoumi, Marzouk and "tearing them to pieces one after the other" (WPZ 1982).

Abjection then is portrayed clearly in Firdaus' killing of Marzouk because he used to obstruct her subjectivity. According to Kristeva, abjection means jettisoning what harms the subject and hinders his autonomy. Getting rid of Marzouk fulfilled Firdaus's autonomy, freedom and self-actualization. Her subjectivity is attained though many acts of abjection she witnessed. After all, she describes herself:

\begin{abstract}
My body was light as a feather, as though its weight had been nothing more than the accumulation of fear over the years ... I walked down the street, my head held high to the heavens, with the pride of having destroyed all masks to reveal what is hidden behind ... my footsteps broke the silence ... they were the footsteps of a woman who believed in herself, know where she was going. (WPZ 1982)
\end{abstract}

Firdaus appears after this process, as a subject who can walk at night with nobody harassing her, as if she is born again because she broke the code of the male patriarchy and knows the secret of how to be born again to locate herself. She developed her subjectivity and founded her name in a male-centered society. Even though she refused to sign an appeal to lessen her punishment and has been executed, Firdaus remains a free subject who deobjectified herself, abjecting by this a whole society.

\title{
6. Conclusion
}

Abjection is traced in WPZ which dissolves the rigid boundaries set by the symbolic order. The abject then is a fundamental tool that calls for the reconsideration of society in order to transform it from a patriarch to egalitarian one.

Hence, through the character of Firdaus, El Saadawi tries to reveal a new order based on, understanding, acknowledging, and uniting with the other, and not based on, excluding, jettisoning and expelling the other. The oppressive patriarchal society, as represented through Firdaus predicaments with the males, lives on the exclusion of the Other, which calls the females to adopt new strategies to liberate and voice themselves. Lesbianism/bisexuality is a 
technique females resort to in order to destroy the patriarchal hegemony. It refers to the possibility of becoming an autonomous (subject) - in - process when rejected and expelled in a patriarchal society. Thus, same-sex discourse, as we had witnessed in the case of Firdaus with the psychiatrist, Iqbal and Sharifa, could be the only means to liberate the self from patriarchal power constraints. Then, the many processes of abjection Firdaus went through, can be considered as potential steps to create an egalitarian society and at the same time, prove Firdaus' subjectivity in the long run, in spite of her being executed at the end.

\section{References}

Barrett, E. (2011). Kristeva reframed: Interpreting key thinkers for the arts. London: I.B. Tauris.

Becker-Leckrone, M. (2005). Julia Kristeva and Literary Theory. Houndmills: Palgrave Macmillan.

Coin, Francesca. (2006). On the Condition of the Colonized Woman: the Nervous Conditions of Firdaus in Nawal El Saadawi's Woman at Point Zero (1983), Giunti, Firenze 2001. DEP.5 (6). Retrieved July 2, 2014, from http://www.unive.it/media/allegato/dep/ Recensioni/37 Sadaawi.rtf

El Saadawi, Nawal. (1983). Woman at Point Zero. trans. by Sherif Hetata. London and New York, Zed Books Ltd.

Emenyonu, E., \& Eke, M. N. (2010). Emerging perspectives on Nawal El Saadawi. Trenton, NJ: Africa World Press.

Grosz, E. (1990). "The Body of Signification," In Abjection, Melancholia and Love: The Work of Julia Kristeva. (J. Fletcher, \& A. Benjamin, Eds.) London: Routledge.

Kristeva, J., \& Roudiez, L. S. (1982). Powers of horror: An essay on abjection. New York: Columbia University Press.

McAfee, N. (2004). Julia Kristeva. New York: Routledge. Internet resource.

Malti-Douglas, F. (1995). Men, women, and God(s): Nawal El Saadawi and Arab feminist poetics. Berkeley: University of California Press.

Rinaldi, J. (2009). Intimacy and violence: Explaining domestic abuse in lesbian intimate partnerships.

Roberts, N. (1992). Whores in History: Prostitution in Western Society. London: Harper Collins.

Roudiez, L. (1984). "Introduction". Revolution in Poetic Language. Trans. Margaret Waller. NY: Columbia UP.

Royer, D. (2000). A Critical Study of the Works of Nawal El Saadawi, Egyptian Writer and Activist. Lewiston: Edwin Mellen Press. 